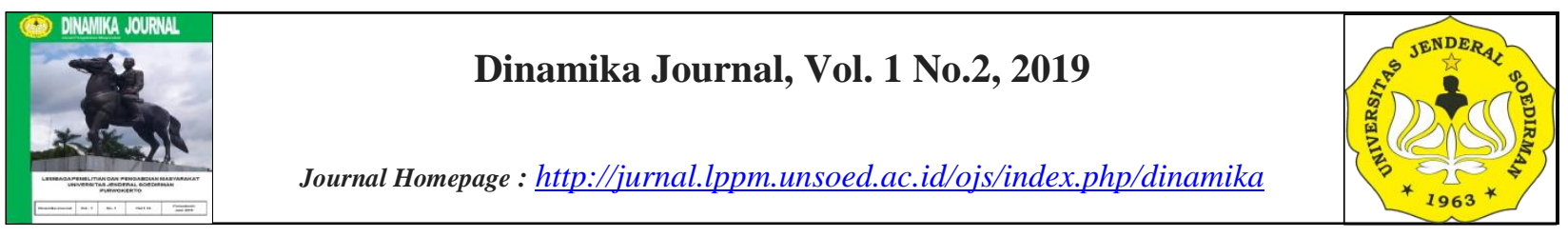

\title{
MENINGKATKAN NILAI TAMBAH PRODUK TAHU MELALUI DIVERSIFIKASI PRODUK MENJADI TAHU BAXO DI DESA KALIKABONG, KECAMATAN KALIMANAH, KABUPATEN PURBALINGGA
}

\author{
Suharno $^{1}$, Emmy Saraswati ${ }^{2}$ \\ ${ }^{1,2}$ Jurusan Ilmu Ekonomi \& Studi Pembangunan, Fakultas Ekonomi dan Bisnis, Universitas \\ Jenderal Soedirman, Purwokerto \\ Corresponding author: suharno@ unsoed.ac.id \\ Received 2 July 2019; Accepted 26 August 2019; Available online 26 August 2019
}

\begin{abstract}
Abstrak
Tuntutan perkembangan dan persaingan aneka produk makanan sudah semakin gencar dan perlu kreatifitas pelaku usaha agar dapat memenangkannya. Meningkatkan nilai tambah suatu produk melalui diversifikasi atas produk awalannya tersebut bukan sebuah keniscayaan. Keadaan tersebut memotivasi penulis untuk tertantang melakukan pengembangan produk tahu biasa menjadi tahu baxo yang banyak disukai oleh kaum millenial. Tulisan ini bertujuan: untuk meningkatkan mutu tampilan dan kualitas kemasan tahu/aneka tahu menjadi lebih menarik; dan untuk meningkatkan volume hasil penjualan pada industri rumah tangga pengrajin tahu sehingga dapat menembus pasar yang lebih luas. Adapun manfaat yang diperoleh yaitu: meningkatnya mutu kemasan dan kualitas produk industri skala rumah tangga pengrajin tahu yang dikemas menjadi lebih menarik. Produk yang telah dikemas dengan kantong plastik tebal $(0,88 \mathrm{~mm})$ akan kedap udara dan memiliki tampilan kemasan yang menarik. Di sisi lain juga akan diperoleh meningkatnya cara penyajian pengrajin tahu melalui diversifikasi tahu baxo dan yang pada gilirannya berakibat meningkatnya permintaan dari produk tersebut sehingga meningkatkan pendapatan masyarakat pengrajin tahu.
\end{abstract}

Kata Kunci : Pengemasan, Pemasaran, Diversifikasi Produk, Aneka Tahu, Tahu Baxo.

\begin{abstract}
The demands for the development and competition of various food products have become more intense, and it requires the creation of businesses to win it. Increasing the added value of a product through diversification of its initial product is not a necessity. This situation motivated the writer to be challenged to do the development of ordinary tofu products into baxo tofu, which is loved by millennials. This paper aims: to improve the quality of appearance and quality of tofu / various tofu packaging to be more attractive, and to increase the volume of sales results in the home industry of tofu artisans so that they can penetrate the full market. The benefits obtained are: increasing the quality of packaging and the quality of the products of the home industry scale of tofu artisans that are packaged to be more attractive. Products that have been packed with thick plastic bags $(0.88 \mathrm{~mm})$ will be airtight
\end{abstract}


and have a beautiful packaging appearance. On the other hand, there will also be an increase in the way of presentation of tofu craftsmen through the diversification of Baxo tofu and this will, in turn, result in increased demand for these products, thereby increasing the income of the tofu craftsmen community.

Keywords : Packaging, Marketing, Product Diversification, Various Tofu, Baxo Tofu

\section{PENDAHULUAN}

Luas Desa Kalikabong seluruhnya 123,40 Ha, mayoritas penduduk desa Kalikabong mempunyai pekerjaan pengrajin tahu, jasa, dan petani. Maka pola pemikiran lahan sangat berkaitan erat dengan mata pencahariannya. Lahan tersebut terbagi atas $103 \mathrm{Ha}$ tanah sawah, 30,035 tanah pemukiman, Tanah pekarangan $20 \mathrm{Ha}$, dan sisanya adalah tanah untuk tempat pendidikan, sungai, lapangan, jalan, pemakaman dan lain-lain.

Potensi Desa Kalikabong, dengan mengembangkan industri skala rumah tangga pembuatan usaha "Tahu" sangat terbuka mengingat desa ini sudah sangat terkenal dengan sentra tahu. Melimpahnya stok tahu di pelbagai dusun di sekitar Desa Kalikabong membuka peluang adanya kegiatan diversifikasi makanan dari tahu ini. Salah satu makanan yang berbahan dasar bekas proses pembuatan tahu adalah tahu baxo, dan tahu bolo. Pengembangan produk tahu menjadi produk-produk olahan mempunyai peluang pasar yang sangat besar, mengingat masih sedikitya jenis-jenis makanan olahan berbahan baku tahu dan ternyata banyak disukai oleh masyarakat, seperti tahu tahu bolu, bolo-bolo dan produk-produk olahan lainnya. Masyarakat Desa Kalikabong, Kecamatan Kalimanah Purbalingga banyak memproduksi tahu sebagai hasil pokok dan sampingan. Ada 4 orang warga yang memproduksi tahu dalam skala cukup besar yang nantinya produk tahu tersebut dijual dalam plastik ukuran $21 \mathrm{~cm}$ x $13 \mathrm{~cm}$ ke pasar-pasar tradisional di Desa Kalikabong. Home industri pembuatan produk tahu ini mempunyai kelemahan, diantaranya: (1) dalam pemasaran dengan kemasan skala besar hanya bisa dijual ke pasar-pasar tradisional, (2) produksi yang dihasilkan dalam lingkungan rumah tinggal menyebabkan tingkat higienis dan sanitasi kurang. Untuk itu perlu dilakukan usaha peningkatan nilai jual tahu menjadi makanan lain yang mempunyai nilai jual lebih tinggi, lebih awet serta banyak digemari masyarakat, yang harapannya nantinya bisa menjadi makanan khas sebagai oleh-oleh dari Desa Kalikabong.

Usaha pembuatan produk tahu sebagai makanan dan oleh-olehan tersebut sudah diterima oleh masyarakat di Desa Kalikabong dan sekitarnya. Produksi dilakukan oleh masyarakat Desa Kalikabong khususnya di daerah kawasan jalan utama desa pada hari dengan menjajakan "Produk Tahu". Kegiatan usaha yang sudah dirintis masyarakat ini masih memiliki kendala berupa pengemasan yang ala kadarnya belum menarik.

Potensi desa yang dapat dikembangkan untuk meningkatkan pendapatan masyarakat dan mengatasi pengangguran tersebut juga potensial guna meningkatkan pendapatan asli daerah (PAD) (Saragih, 2015). Pada era otonomi daerah, banyak daerah yang terjebak pada upaya peningkatan PAD yang justru memberatkan masyarakat, misalnya dengan meningkatkan pajak dan retribusi daerah, oleh karena itu pengembangan pototensi wilayah dapat dijadikan salah satu solusi. Peningkatan PAD dengan meningkatkan pajak dari masyarakat merupakan jalan pintas yang kontradiktif dengan tujuan pembangunan itu sendiri (Kimbal, 2015). Melalui upaya dengan meningkatkan usaha ekonomi produktif masyarakat, misalnya dalam bentuk penerapan Ipteks bagi industri rumah tangga (home industry) maupun usaha kecil menengah (UKM) yang selama ini ada, serta optimalisasi potensi desa (SDA maupun SDM) yang dimiliki (Solihin, 2014). Apabila pendapatan masyarakat meningkat, 
dipastikan penerimaan asli daerah (PAD) ikut meningkat (Puspitasari, 2015). Pada gilirannya nanti, diharapkan dapat mengentaskan masyarakat dari kemiskinan menuju masyarakat sejahtera dengan terpenuhinya ketersediaan pangan juga mutu pendidikan dan kesehatan masyarakat ikut meningkat.

Kecamatan Kalimanah pada Desa Kalikabong yang terpilih tersebut, memiliki potensi untuk dapat dikembangkan. Kegiatan pengabdian kepada masyarakat memandang perlu Desa Kalikabong dijadikan tempat kegiatan karena potensinya yang masih sangat baik untuk dikembangkan. Potensi industri skala rumah tangga yang memproduksi tahu selanjutnya diolah menjadi produk tahu dapat mendukung potensi wisata Kawasan Purbalingga sebagai buah tangan (oleh-oleh). Kendala atau kelemahan pemasaran oleh-oleh tersebut belum menarik tampilannya khususnya kemasan produk sehingga perlu sentuhan Ipteks.

Berdasar analisis situasi di atas dapat diketahui permasalahan utama yang dihadapi pengrajin industri produk tahu skala rumah tangga adalah dari sisi pemasaran produk terutama penanganan pasca produksi tentang pengemasan yang kurang baik. Selama ini pengrajin hanya membungkus hasil industrinya ala kadarnya yang penting dapat diukur unitnya bahkan kadang setelah diukur atau ditimbang dibungkus dengan kantong plastik saja. Sehingga memiliki kelemahan (1) dari sisi keawetan produk karena kemasan yang tidak rapat akibatnya udara mudah masuk; (2) dari segi penampilan tidak menarik dan kalah dengan produk substitusinya.

\section{METODOLOGI}

Kerangka pemecahan masalah dalam tulisan ini dilakukan dengan pemecahan masalah melalui (Budiarti, 2016) :

(a) Peningkatan mutu kemasan produk tahu yang dikemas menjadi lebih menarik. Produk akan dikemas dengan kantong plastik tebal $(0,88 \mathrm{~mm})$ yang kedap udara.

(b) Produk memiliki tampilan kemasan plastik yang bersablon warna-warni menarik dengan mencantumkan bahan-bahan pembuat produk tahu dan tanggal kadaluarsa,

(c) Peningkatan cara pemasaran aneka produk tahu melalui pasar modern/ supermarket dan instansi/kampus.

Realisasi pemecahan masalah dilakukan melalui kegiatan praktik pengemasan, pemasaran, penyuluhan dan pendampingan ini dilaksanakan pada 4 orang pengrajin produk tahu di Desa Kalikabong Kecamatan Kalimanah dengan materi-materi sebagai berikut :

1. Cara Mengemas produk tahu

2. Cara Memasarkan

3. Cara Memasarkan aneka produk tahu Di Pasar Tradisional

Khalayak sasaran adalah industri rumah tangga atau pengrajin usaha pembuatan jajanan berbahan baku produk tahu yang diusahan oleh masyarakat Desa Kalikabong. Kegiatan penerapan Ipteks ini yang dijadikan khalayak sasaran adalah pengrajin industri produk tahu skala rumah tangga. Di Desa Kalikabong tersebut yang sudah terdapat pengrajin.

Khalayak sasaran dalam pengabdian masyarakat ini adalah para pengrajin industri skala rumah tangga yang memiliki usaha kecil berupa usaha membuat jajanan atau makanan ringan dari produk tahu. Adapun pengrajin industri rumah tangga sejumlah 4 orang. Apabila kegiatan ini berhasil diharapkan membangkitkan motivasi keluarga yang lain untuk mengembangkan usaha industri rumah tangga dengan beraneka produk. Banyaknya pengusaha yang tumbuh di Desa Kalikabong akan menggerakan industri masyarakat sekitar

8 Dinamika Journal Vol. 1 No. 2, Agustus 2019 : 6 - 11 
khususnya Kecamatan Kalimanah Kabupaten Purbalingga yang selanjutnya dapat meningkatkan pendapatan dan mengurangi jumlah pengangguraan.

Sasaran atau obyek ini adalah 4 orang pengrajin produk tahu di Desa Kalikabong Kecamatan Kalimanah Kabupaten Purbalingga.

Metode yang digunakan berdasarkan hasil observasi tim pengabdian kepada masyarakat seperti yang telah diuraikan pada analisis situasi dan identifikasi perumusan masalah di atas, maka tim berinisiatif untuk menambah ketrampilan dan pengetahuan kepada pengrajin industri skala rumah tangga. Praktik ketrampilan untuk masyarakat pengrajin yang mengelola usaha industri rumah tangga. Jenis ketrampilan yang diberikan berupa cara-cara meningkatkan pemasaran hasil industri rumah tangga guna meningkatkan pendapatan keluarga. Salah satu upaya meningkat pemasaraan dengan mendampingi industri rumah tangga mengemas hasil produknya. Kegiatan pendampingan selain diberi praktik pengemasan juga teori praktis tentang mengelola usaha kecil, kewirausahaan, dan kelompok usaha bersama.

Kegiatan ini agar pengrajin industri rumah tangga mampu mengelola usaha di Desa Kalikabong sehingga dapat meningkatkan pendapatan keluarga. Dampak positif dari peningkatan keluarga pengrajin industri skala rumah tangga yaitu lancarnya perekonomian desa dengan terserapnya tenaga kerja melalui penciptaan lapangan kerja sendiri.

Metode kegiatan pengabdian kepada masyarakat berupa penerapan Ipteks ini memakai metode pendampingan dengan dua kegiatan.

1. Kegiatan teoritis praktis untuk meningkatkan pemasaran hasil melalui pendidikan dan pelatihan pengemasan yang baik dan benar, mengelola usaha kecil, kewirausahaan, dan kelompok usaha bersama.

2. Kegiatan pendampingan dan praktik pengemasan yang baik dan benar dengan label produk hasil industri rumah tangga Desa Kalikabong Kecamatan Kalimanah untuk meningkatkan pemasaran.

\section{HASIL DAN PEMBAHASAN}

Metode kegiatan pengabdian kepada masyarakat berupa penerapan Ipteks ini memakai metode pendampingan dengan dua kegiatan yang terukur:

1. Kegiatan praktik berupa pengenalan aneka produk tahu berupa tahu baxo dan tahu bolo untuk meningkatkan skala produksi dan pemasarannya. Pelatihan untuk memodifikasi berbagai produk dilakukan dalam dua pertemuan. Pertemuan pertama dihadiri oleh 4 pembuat tahu. Pertemuan dimulai dengan diskusi terkait pengalaman dalam membuat berbagai produk tahu yang dilakukan oleh masing-masing peserta. Diskusi ini menghasilkan kesimpulan bahwa cita rasa produk yang sejauh ini telah diproduksi oleh peserta yang berbeda, karena komposisi bahan yang berbeda satu sama lain. Maka disepakati bahwa komposisi bahan yang sama agar menghasilkan rasa produk yang lebih baik. Mempersiapkan pertemuan berikutnya, setiap peserta diminta untuk menyajikan dua jenis tahu. Jenis pertama adalah tahu bolo yang biasanya diproduksi oleh mitra, maka tipe kedua adalah tahu Baxo dengan komposisi bahan yang disepakati. Hasil tahu bolo yang dibuat dibawa ke pertemuan berikutnya. Pertemuan kedua pelatihan modifikasi rasa produk dihadiri oleh 4 pembuat tahu yang berbeda. Sebagaimana dinyatakan pada akhir pertemuan sebelumnya bahwa setiap peserta diminta untuk membawa dua jenis Aneka Tahu. Jenis pertama adalah sesuai dengan komposisi bahan yang biasa diproduksi oleh mitra, sedangkan jenis kedua adalah komposisi bahan yang disepakati. Tim pelaksana bersama-sama dengan staf 
lapangan melakukan uji rasa pada dua jenis berbagai tahu yang telah diproduksi. Skala 1-5 digunakan untuk menilai selera atau rasa tahu, dari skala 1 tidak baik untuk skala 5 sangat baik. Uji rasa dilakukan dengan metode pengkodean, yang menyediakan pengkodean untuk masing-masing dari berbagai tahu yang diproduksi oleh pembuat tahu dengan kode yang telah ditentukan untuk masing-masing pembuat dengan tanda TBO (Tofu Bolo Original) untuk tahu yang menggunakan komposisi bahan secara normal diproduksi oleh masing-masing mitra, sedangkan TBM (Tofu Baxo Modification) untuk komposisi bahan yang disepakati. Kemudian hasil uji rasa tahu aneke sebagai berikut:

Tabel 1. Hasil Penyajian Tahu

\begin{tabular}{|c|l|c|c|}
\hline Kode & Nama Penyaji & TBO & TBM \\
\hline 1 & A & 3 & 3 \\
\hline 2 & B & 4 & 3 \\
\hline 3 & C & 4 & 2,5 \\
\hline 4 & D & 4 & 3 \\
\hline \multicolumn{2}{|c|}{ Rata-rata } & 3,8 & 2,9 \\
\hline
\end{tabular}

2. Kegiatan pendampingan dan praktik pemasaran yang baik dan benar dengan label produk hasil tahu Desa Kalikabong Kecamatan Kalimanah. Tim pengabdi mengeksplorasi sejumlah pencetakan kemasan dan toko-toko plastik agar sesuai dengan desain kemasan yang disepakati antara tim pengabdi dan mitra. Selain itu, tim pelaksana juga mempertimbangkan nilai ekonomis paket, karena setelah program ini diharapkan bahwa label ini akan terus digunakan. Penggunaan kemasan telah dirancang dan disepakati, selanjutnya tim pelaksana memutuskan untuk membuat kemasan dari bahan plastik setelah mempertimbangkan ukuran yang tersedia, kecil, sedang dan besar. Setelah itu, tim pelaksana menyerahkan kepada desainer pengemasan untuk merancang desain pengemasan yang akan digunakan. Kriteria desain kemasan yang berfungsi sebagai referensi bagi desainer adalah untuk menunjukkan identitas UMKM, dan kejelasan merek / branding.

Melihat fenomena yang ada, maka kegiatan praktik yang seperti itu masih harus terus dilaksanakan bukan hanya di Desa Kalikabong Kecamatan Kalimanah saja, tetapi juga di tempat-tempat lain, agar masyarakat pengrajin tahu Indonesia khususnya lebih mengetahui tentang cara pemasaran ini, yang kemudian ada ketertarikan lebih lanjut untuk menerapkan pengembangan pemasaran usaha dalam kehidupan sehari-hari.

Faktor pendorong kegiatan ini bisa berjalan dengan lancar karena didorong oleh beberapa faktor diantaranya ialah :

1. Dukungan pengrajin produk tahu yang begitu antusias membantu pelaksanaan kegiatan ini.

2. Masyarakat setempat yang antusias mengikuti kegiatan ini.

3. Kesiapan para penyaji yang menyampaikan materinya dengan cukup baik.

Faktor penghambat secara umum tidak ada hambatan yang berarti dalam kegiatan ini, hanya saja terbatasnya sinar matahari sebagai media penjemuran tahu ketika masih mentah menyebabkan stok produksi produk tahu menjadi berkurang apabila tidak ada sinar matahari. Kendala produksi tersebut dapat menganggu praktik pemasaran apabila sudah mendapat 
kepercayaan untuk memasok di supermarket modern yang memerlukan kepastian jumlah produksi setiap minggunya.

\section{KESIMPULAN}

Usaha produksi berupa produk aneka tahu perlu terus ditingkatkan dengan menciptakan inovasi-inovasi berupa rasa tahu dan bentuk produk aneka tahu lainnya. Informasi dan praktik tentang adanya pengemasan tahu memakai sistem labeling dan pengemasan modern secara umum masih harus disosialisasikan kepada masyarakat pengrajin makanan kecil yang sifatnya masih tradisional.

Sosialisasi tentang pengemasan ini harus menyertakan para praktisi di lembaga dinas terkait dan UMKM, agar penjelasan tentang praktek pengembangan usaha ini lebih menyeluruh sampai ke masalah teknis.

Kegiatan ini mendapat respon yang sangat baik dari masyarakat pengrajin produk tahu, karena bisa menjawab ketidakjelasan di masyarakat tentang praktek ini.

Seharusnya para penyuluh, para pakar labeling dan pihak-pihak yang berkompeten lebih proaktif untuk mensosialisasikan tentang praktek labeling pada masyarakat, apalagi ke pelosok-pelosok daerah, agar masyarakat yang awam terhadap metode ini bisa mendapatkan informasi yang lengkap, sehingga mendorong mereka untuk lebih memperoleh keberhasilan dalam pengelolaan usaha kecilnya.

\section{UCAPAN TERIMA KASIH}

Terima kasih kepada Direktorat Riset dan Pengabdian Masyarakat, Direktorat Jenderal Penguatan Riset dan Pengembangan, Kementerian Riset, Teknologi, dan Pendidikan Tinggi Kontrak Nomor: 059/SP2H/PPM/DRPM/2019 Tahun Anggaran 2019 yang telah memberikan dana pengabdian kepada masyarakat dari skema hibah Program Kemitraan Masyarakat .

\section{DAFTAR PUSTAKA}

Budiarti, S. 2016. Karakteristik industri tahu di Desa Trimurti Kecamatan Srandakan Kabupaten Bantul. Geo Educasia-S1, 1(2).

Kimbal, R. W. 2015. Modal Sosial dan Ekonomi Industri Kecil: Sebuah Studi Kualitatif. Deepublish.

Puspitasari, D. C. 2015. Wirausaha Muda Membangun Desa: Dinamika Partisipasi Pembangunan Desa. Jurnal Studi Pemuda, 4(2), 330-341.

Saragih, J. R. 2015. Perencanaan wilayah dan pengembangan ekonomi lokal berbasis pertanian: teori dan aplikasi. Pustaka Pelajar.

Solihin, I. 2014. Pengantar Bisnis. Penerbit Erlangga. 